\title{
UTILIZATION OF TECHNOLOGY IN LEARNING ENGLISH IN THE PANDEMIC COVID-19
}

\author{
Abdul Gafur Marzuki \\ IAIN Palu \\ Santiana \\ Siliwangi University
}

The use of technology in the learning process both inside and outside the classroom, both online and offline plays a crucial role. Technology plays a role as a medium in carrying out interactions between lecturers as teachers and students as students in the application of learning, especially online learning during the Covid-19 pandemic. Technology plays an important role in facilitating lecturers in preparing learning materials so that the process can take place even if not face to face. However, the process of implementing online learning does not escape from various obstacles, and the biggest obstacle that is a challenge for learning practitioners is related to the readiness of facilities and the ability of lecturers to use learning technology applications. The implementation of training related to the use of technology applications in learning can be a solution in facing some of the challenges of online learning during the Covid-19 pandemic (Manowong, 2016; Wichadeeq, 2017; Marzuki, 2019; Alek et al., 2020).

Currently, technological developments in learning continue to develop rapidly with the presence of a wide selection of applications both online and offline. Some examples of the most widely used platforms today in implementing online English learning are Canvas, Moodle, Schoology, Edmodo, Google Classroom, Quizziz, Kahoot, and Duo Lingo. Meanwhile, the most widely used applications for virtual encounters are Zoom, Google Meet, and Webex (Al-Naibi, 2018; Karimah et al., 2018; Izza et al., 2020).

The development of technology in learning has also facilitated and made it easier for lecturers and students to interact online. Several learning technologies that can be used in online learning are Edmodo, Quizziz, Kahoot, and Duo Lingo applications. These applications are applications or webs that consist of a group of people, namely teachers and students, which contain several features which are very helpful in the smoothness of the online learning process. These applications as learning platforms have been designed to maximize the achievement of 
learning objectives and facilitate the learning process online (Fauzi, 2017; Gay \& Sofyan, 2017; Marzuki, 2017; Alsmari, 2019; Larassati, 2020).

Edmodo application, for example, acts as a social learning network or Social Learning Network (SLN) with features that serve as a medium for sharing learning resource information, interacting and communicating between lecturers and students, among students, and evaluating learning outcomes. Online through feedback provided by lecturers (Larassati, 2020). Edmodo can be used either by opening the website or by downloading the Edmodo application in the play store on Android. The main features of Edmodo are online learning material and online evaluation (Warawudhi, 2017; Hadi \& Rulviana, 2020). The Edmodo application was designed by Nicolas Borg and Jaff O'Hara with a platform to collaborate between lecturers and students.

According to Larassati (2020), Edmodo is a learning application that is widely used today, because besides being easy to operate, it also does not require a large internet quota so that it saves quotas and pleases students' pockets. The features contained in Edmodo are as follows: (1) Polling, a feature that is only specifically used by lecturers, this feature serves to find out student responses. (2) Gradebook, a record of student grades. (3) Quiz, a feature where the lecturer makes a Quiz as an online evaluation to find out how far students understand the material that has been taught. (4) File and Links, is a useful feature for sending notes with file attachments and links, files can have the extension .doc, .pptx, .xls, .pdf and others. (5) Library, which functions as a place to store various data, lecturers can upload teaching materials such as presentation materials, pictures, videos, and other reference sources. (6) Assignment, useful for assigning assignments to students online, the advantages of this feature are that it is equipped with a time limit, attach files that allow students to send assignments directly. (7) Award Badge, useful for giving awards to students, (8) Parent Code, functions for parents of students to monitor their children's learning activities.

The use of Edmodo in learning English plays an important role, especially in the pandemic era, where learning must be carried out online. Several survey results related to online learning, show that students prefer offline learning or face-to-face learning in class. Online learning can also cause boredom for lecturers and students, besides they must have an adequate internet quota. On that basis, lecturers are required to be more creative in designing teaching materials, using Edmodo applications, and presenting materials online. One way to increase student motivation in online learning is to use other $\mathrm{p}$ applications such as the Quizziz, Kahoot, and Duo Lingo 
applications in learning English. The combination of these applications will make the learning process more interactive, interesting, and fun (Erdemir \& Ekşi, 2019; Hamidah, \& Nurmatin, 2020).

The effectiveness of learning using technology, namely the use of Edmodo, which is assisted by other learning applications, will be able to improve and fulfill four indicators, namely indicators of the ability of lecturers to manage learning, indicators of student activity, indicators of student responses and indicators of student response with good criteria. In other words, learning carried out using Edmodo is effectively applied in learning both English and other subjects (Kadir, 2020). The proper management of learning from lecturers will have an impact on students. The ability of the lecturer in managing learning can be observed by looking at several criteria, namely: the ability of the lecturer in preliminary activities, core activities and closing activities. The indicators observed are: a) Delivering Learning Objectives, b) Motivating Students, c) Explaining learning steps with Edmodo, d) Designing material on Edmodo Application, e) Guiding students to discuss, f) Providing explanations of student questions, g) Summing up the learning materials, h) Giving homework through the Edmodo application, i) Managing time during learning, and j) Classroom atmosphere (Kadir, 2020).

In addition, student activity indicators can be monitored in Edmodo class. Student response indicators can also be known directly, so that lecturers can find out active students and students who are less active in online learning (Susanti, \& Effendi, 2020).

Based on various references to scientific articles and the author's practical experience, most students stated that learning using Edmodo combined with other learning technology applications can be said to be effective. Effectiveness is seen from the response and enthusiasm of students in taking part in online learning and the results of evaluation both from daily evaluations in the form of quizzes, midterm exams, and final semester exams. So that the use of learning technology in the online learning process in the independent era of learning during the Covid-19 pandemic is effective and highly recommended, provided that both lecturers and students must first master and be able to use these learning technology applications. 


\section{REFERENCES}

Alek, A., Marzuki, A. G., Farkhan, M., \& Deni, R. (2020). Self-Assessment in Exploring EFL Students' Speaking Skill. Al-Ta lim Journal, 27(2), 208-214.

Al-Naibi, I. H., Al-Jabri, M., \& Al-Kalbani, I. (2018). Promoting Students' Paragraph Writing Using EDMODO: An Action Research. Turkish Online Journal of Educational Technology-TOJET, 17(1), 130-143.

Alsmari, N. A. (2019). Fostering EFL Students' Paragraph Writing Using Edmodo. English Language Teaching, 12(10), 44-54.

Erdemir, N., \& EKŞİ, G. Y. (2019). The perceptions of student teachers about using an online learning environment 'Edmodo'in a 'flipped classroom'. SDU International Journal of Educational Studies, 6(2), 174-186.

Fauzi, A. (2017). The effect of Edmodo on students' writing skill in recount text. International Journal of Pedagogy and Teacher Education, 1(2), 73-79.

Gay, E., \& Sofyan, N. (2017). The effectiveness of using Edmodo in enhancing students' outcomes in advance writing course of the fifth semester at FIP-UMMU. Journal of English Education, 2(1), 1-11.

Hadi, F. R., \& Rulviana, V. (2018). Analisis Proses Pembelajaran E-Learning Berbasis Edmodo pada Mata Kuliah Geometri. Jurnal Bidang Pendidikan Dasar, 2(1), 63.

Hamidah, \& Nurmatin, S. (2020). Pelatihan Pembelajaran Daring Menggunakan Edmodo. 1(1). http://ojs.staitasik.ac.id/index.php/al-abhats/index

Izza, A. Z., Falah, M., \& Susilawati, S. (2020). Studi Literatur: Problematika Evaluasi Pembelajaran Dalam Mencapai Tujuan Pendidikan Di Era Merdeka Belajar. Konferensi Ilmiah Pendidikan Universitas Pekalongan 2020, 10-15. Retrieved from https://proceeding.unikal.ac.id/index.php/kip

Kadir. (2020). Efektivitas Pembelajaran Matematika Berbasis Edmodo di MAN Lhokseumawe. Jurnal Numeracy. 7(1), 79-94.

Karimah, S., Utami, R., \& Hidayah, N. (2018). Keefektifan Media Pembelajaran Berbasis Edmodo terhadap Kreativitas Mahasiswa. Jurnal Pendidikan Edutama, 5(2), 97. https://doi.org/10.30734/jpe.v5i2.132

Larassati, M. A. (2020). Evektifitas Media Pembelajaran Daring Edmodo dalam Perkuliahan Pendidikan Agama Islam pada masa Pandemi Covid-19. http://jurnal.uts.ac.id.

Manowong, S. (2016). Undergraduate students' perceptions of Edmodo as a supplementary learning tool in an EFL classroom. Humanities, Arts and Social Sciences Studies (Former Name Silpakorn University Journal of Social Sciences, Humanities, And Arts), 137-162.

Marzuki, A. G. (2019). Utilizing Recorded English Dialogues in Teaching English Word Stress to Islamic Higher Education Students in Indonesia. Jurnal Pendidikan Islam, 5(1), 53-64.

Marzuki, A.G. (2017). Developing Speaking Skill through Oral Report in an EFL Class in Indonesia, Al-Ta'lim Journal, 24(3), 243-254.

Susanti, R. D., \& Effendi, M. M. (2020). Efektivitas Penggunaan Edmodo Dalam Pelaksanaan Ulangan Harian Matematika. FIBONACCI: Jurnal Pendidikan Matematika Dan Matematika, 6(1), 9-16.

Warawudhi, R. (2017). The evaluation of Edmodo in business reading class. International Journal of Information and Education Technology, 7(2), 153. 
Wichadeeq, S. (2017). A Development of the Blended Learning Model Using Edmodo for Maximizing Students' Oral Proficiency and Motivation. International Journal of Emerging Technologies in Learning, 12(2). 